\title{
Service Quality of Public Technical Vocational Education and Training Colleges in South Africa: Customer Expectations and Perceptions
}

\author{
Nkululeko Praise God ZUNGU, Lawrence Mpele LEKHANYA \\ Durban University of Technology, Durban, South Africa \\ n.p.1zungu@gmail.com, lawrencel@dut.ac.za
}

\begin{abstract}
The focus of this survey is to seek the amount of the customers' expectations levels of service quality in the public Technical Vocational Education and Training (PTVET) sector. The aim of this study was to examine and determine the expectations and perceptions levels of service quality provided by PTVET colleges, in order to achieve desired outcomes, and the survey followed SERQUAL model. Questionnaires were distributed to the 403 participants from selected PTVET in the Kwa-Zulu- Natal province. The study used a mix approach of systematic and quota sampling techniques. SPSS (25.0) version was employed for data analysis. The results of this study discovered that customers had higher service quality expectations $(0,908$ Cronbach's Alpha) compared to the service quality perceptions $(0,923$ Cronbach's Alpha) at the selected PTVET colleges, on all five service quality dimensions that were used to evaluate the expectations of service quality. This survey will benefit Rectors/Campus Managers for TVET colleges and to those who want to open their TVET colleges, because it will be used as a guide tool for them on how they can improve service quality strategy to differentiate themselves from their competitors. The findings are limited by the study's exploratory, quantitative nature and small sample. Generalisation should be done with care and further research, with a large sample and consideration of other provinces, it therefore recommended.
\end{abstract}

Keywords: Service Quality, Customers Perceptions, Customer Expectations, PTVET, SERVQUAL, GAP, South Africa

\section{Introduction}

In South Africa, Public Technical Vocational Education and Training (PTVET) colleges were recognized and functioned with regard to South African Education Act 16 of 2006 and further it was amended under Act (No. 3 of 2012) where these colleges were called Further Education and Training (FET) Colleges then they became to be under the Department of education and training and they were supported and mandated to provide vocational skills. These colleges provide broader knowledge in various areas such as artisans and many other vocational skills need by South African society as well as modern business and industries of nowadays. This premise supported by Shirley, Chijioke and Chukwumaijem (2015) that PTVET empowers society with a much required technical and vocational skill for the modern business in today's extremely complex turbulent environment. Mohd, Mohd \& Ruhizan (2012) believe that in recent times, entities must have well prepared human capital in order for them to deliver the quality of services that meet customers' expectations. Therefore, this study intends to look into different factors contributing to the perceptions and expectations of PTVET colleges customers.

Problem Statement: The high numbers of students who finished and qualified for tertiary degree and diplomas in the province of KwaZulu-Natal has demonstrated that traditional and universities of technologies cannot able to provide space for all of them (Wolhuter, 2017). This is the major problem facing South African government, therefore, South African government was forced to look of the alternative for the after matric students, hence the PTVET was found to be the option, however, local communities have raises many doubts about the service quality in PTVET colleges. The intention of this study was to establish understand and knowledge of service quality in PTVET colleges. Pillay, Mbambo, \& Mason, (2017) indicated that quality perceived to be a concern for many the in PTVET.

Aims and Objectives: The aim of this study was to examine and determine the expectations and perceptions levels of service quality provided by PTVET, in order to achieve desired outcomes, and the survey followed SERQUAL model.

Objectives: To identify expectations and perceptions of customers towards service quality at the PTVET colleges in KZN; and evaluating extent of the existing gaps on expectations and perceptions of customers in 
the selected PTVET colleges in KZN. Hence, PTVET colleges must first understand students' expectations as the basis for developing and delivering quality service.

\section{Literature Review}

South African PTVET Colleges: There is a total of 260 campuses for PTVET colleges which are made of 50 multi-campuses operating according to the continuing education Act of 16 of 2006 which categorized under South African department of higher education and training. The main purpose of these institutions (PTVET) is to prepare South African Youth with the relevant practical and occupational skill that is needed by the industry. Shirley, Chijioke and Chukwumaijen (2015) believe that TVET provided much-needed knowledge on the changing technological environment and workforces' skills needed by the current economy. According to Bünning \& Zhao, 2006), vocational skills can bring effectiveness and relevance to the South African citizens and enhance the quality and employability in particular KwaZulu-Natal province.

Service Quality Concept: PTVET needs to improve and engage much on the service quality concept and use it as a positioning and competitive tool to compete with other institutions of higher learning. Before PTVET college personnel uses service quality as a tool, it is very important to start by taking getting understanding of service quality concept. Based on that conceptualization of service quality the concept of service quality is all about the perception of the customer towards service (Wilson, Zeithaml, Bitner \& Gremler (2013). However, Hult, Pride and Ferrell (2012), Weitz \& Wessley cited in Phiri \& Mcwabe (2013) mentioned service quality concept as for how well the service provider meets or exceeds their customer expectations. Machado \& Diggines (2012), and Boshoff \& du Plessis, 2010) supported this statement by indicating that, quality of service is being assessed by customer's decision about the level of service performance. What is noted about these aforementioned definitions of service quality concept is that, researchers, academics and authors uses diverse ways to define service quality concept, but all definitions of service quality concept are grounded on exceeding customer expectations. Furthermore, inferring from the above definitions, service quality in education could be defined as students' measurement or evaluation of how service delivered by PTVET college matches with the expectations of the students. This indicates that the quality of service delivered is defined by the students and not by Technical and Vocational Education and Training colleges.

Customer Expectations of Service Quality: Zeithaml, Bitner \& Grender (2006) well-defined customer expectations as viewpoints around service delivery that function as criteria against which performance is tried by customers. Whereas, Zeithaml, Bitner, Grender \& Dwayne, (2008) pointed out that expectations of customers are viewpoints about service superiority, serving as principles compared to which performance of the organisations is judged by their customers. This will also useful to public PTVET college's customers. It is very imperative for public PTVET colleges also to note that, customers do not have same desires regarding their model quality level and they differ in the extent on which they tolerate a certain lack of quality. The market-oriented service provider (including PTVET College). However, endeavours to meet the individual expectations of their customers (Boshoff, 2014). The levels of service quality expectations and perceptions were quantified by calculating the average scores on each statement.

Customer Perceptions of Service Quality: The challenge facing the service providers is that, if customers have excellent knowledge on quality that exceeded their expectations by far, they may raise their expectations to new levels. The expectations of customers can be influenced by factors such as word-ofmouth, communication experience and TVET colleges' charges. Meeting customer expectations and satisfying their needs are important elements in the PTVET college effort to retain its customers and gain a competitive advantage over their competitors. Many Academics, Researchers, as well as Scholars conducted research on customer perception concept, those include Schiffman \& Kanuk (2000); Strydom, Jooste \& Cant (2000); Sheth \& Mittal (2004); Cant, Brink \& Brijball 2002); Hult, Pride \& Ferrell (2013) defined perception as a process of selecting, organizing, and interpreting information inputs to produce meaning and coherent picture of the world. Whereas, Zimmerman \& Blythe (2014) describe perception as a process of converting sensory input into an understanding of how the world works. Customers' perception regarding service quality depends upon the gap that exists between what the customers expect and what they receive in the service (Parauraman cited in Khare, 2011). It becomes imperative for PTVET colleges in KwaZulu-Natal to understand the expectation levels of the customers, and design service delivery according to their 
expectations. Delivering a service according to customer expectations and superior quality of service enhances the competitive advantage of PTVET colleges with other private TVET colleges and help in retaining customers. Perceptions of customers become an influential factor when comparing customers' satisfaction with the service that is provided to them Khare, (2011).

\section{Research Methodology}

A questionnaire survey was employed to identify customer expectations and customer perception of the selected PTVET colleges: Case KwaZulu-Natal, South Africa, with specific emphasis on factors contributing to the customer expectations and contributing to the customer perception; to examine to what extent are these factors affecting expectations and perceptions and provide suggestions for the solution.

Sample Design: The below table 1, clearly shows that, a sample size of 403 customers was selected from the selected PTVET colleges campuses in KwaZulu-Natal. The survey followed a mixed method approach. Quota sampling technique was employed in order to, allowed the flow of data representatives. The students on the campuses and employees were identified respondents for this study as presented in Table 1.

Table 1: Sample Size per PTVET College Campus

\begin{tabular}{ll}
\hline PTVET College & Sample size per campus \\
\hline PTVET College Campus A & 67 \\
PTVET College Campus B & 67 \\
PTVET College Campus C & 67 \\
PTVET College Campus D & 67 \\
PTVET College Campus E & 67 \\
TOTALS & 403 \\
\hline
\end{tabular}

Survey Instrument Design: A questionnaire was developed from the literature reviewed followed the standard SERVQUAL questionnaire format, and this survey questionnaire consisted of two sections, covering service quality expectations and service quality perceptions statements. Then, questionnaire consisted of twenty-two statements of service elements groups into five service quality dimensions which include tangible of service quality dimension, assurance of service quality dimension, the reliability of service quality dimension, the responsiveness of service quality dimension, and empath of service quality dimension. The respondents were asked to provide the ratings of both expectations and perceptions on the provided statements related to service quality. Thus the difference obtained from the service quality perception scores discovered the gap between customers' expectations and their perceptions of the service quality of the selected PTVET colleges.

\section{Discussion of the Findings}

The analysis of empirical data was done by assessing PTVET customers' responses of their levels of agreement with regards service quality statements that were used to assess customers' expectations of service quality at an excellent PTVET college and perceptions of service quality at the selected PTVET colleges in KwaZulu-Natal, South Africa. The levels of service quality expectations and perceptions were measured by calculating the average mean score on each service quality statement. Mean scores were obtained from calculating the averages for expectations were subtracted from customers' perceptions of each service quality statement. All these were done by the use of SPSS (25.0) version. The findings of this study discovered that PTVET customers had a higher level of expectations compared to their perceptions of the service quality at the selected PTVET colleges on all five service quality dimensions that were used to assess customers' expectations and perception of service quality. 


\section{Samples Profile}

Table 2: Respondents' Race Groups

\begin{tabular}{lll}
\hline Race group & Frequency & $\mathbf{\%}$ \\
\hline Black African & 360 & 89,3 \\
Indian & 25 & 6,2 \\
Coloured & 15 & 3,7 \\
White & 3 & 0,7 \\
Total & $\mathbf{4 0 3}$ & $\mathbf{1 0 0}$ \\
\hline
\end{tabular}

As shown in Table 2 that PTVET colleges in KwaZulu-Natal are dominated by black African. Out of 403 of respondents, 360 (89, $3 \%$ ); followed by Indian with 6, $2 \%$ (25 respondents); and 3, $7 \%$ (15 respondents) are Coloured. Only 0, $7 \%$ (3 respondents) were representing White respondents. The results are the true reflection of the KwaZulu-Natal population.

Figure 1: Respondents Race Groups

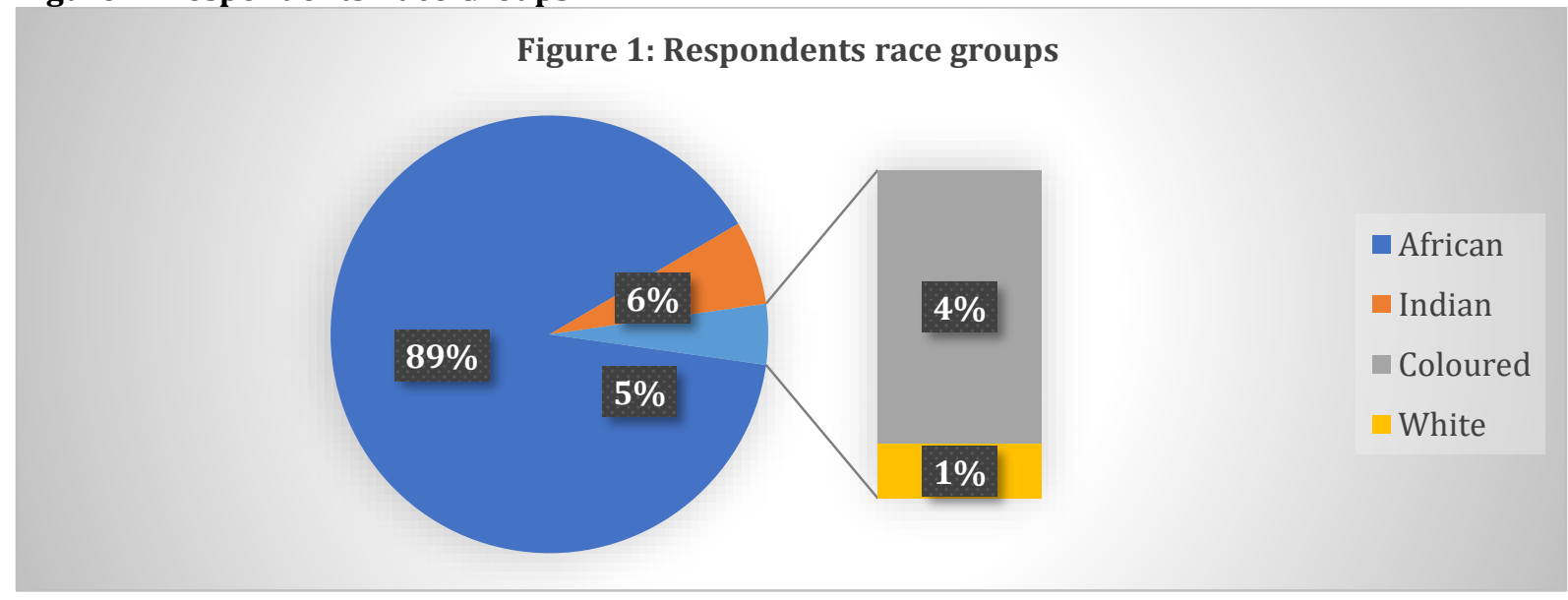

The researcher decided to use the above chart to show the proportions of a whole, by taking some values from the first pie and combined them in a stacked bar to highlight the values in the stacked bar. The results of this study also confirm that, $89 \%$ of the participants are Black African, followed by Indian with $6 \%$ and $5 \%$ for Coloured (4\%) and White (1\%), as shown in figure 1 . Even though other race groups have a small number of respondents but, it is also very imperative to know their views about how they feel about the service provided to them. Furthermore, their input or views can assist PTVET colleges to improve the way they provide service to them and they will able to know what are their expectations. Scores obtained from calculating the averages for expectations were subtracted from the scores from customers' perceptions on each statement of each service quality dimension. Perceptions and Expectations of Service Quality Dimensions Analysis PTVET Colleges were done on and presented in the following sections.

\section{Reliability Statistics}

Table 3: Cronbach's Alpha Analysis for Respondents' Expectations

\begin{tabular}{lll}
\hline Service Quality Dimension & $\begin{array}{l}\text { Expectations } \\
\text { N of Items }\end{array}$ & Cronbach's Alpha \\
\hline Tangibles & 4 & 0,639 \\
Assurance & 4 & 0,717 \\
Reliability & 5 & 0,833 \\
Responsiveness & 4 & 0,794 \\
Empathy & 5 & 0,783 \\
Overall & 22 & 0,908 \\
\hline
\end{tabular}


The reliability score in terms of expectation of service quality dimensions (Assurance, Reliability, Responsiveness and Empathy), record 0.717, 0.833, 0.794 and 0.783 respectively (as shown in table 3), which values for expectations exceeded the 0.70 reliability threshold for exploratory research. However, the reliability score of service quality dimension will be considered as good because its score is over 0.80 as recommended by Islam, et al. (2011).

Table 4: Cronbach's Alpha Analysis for Respondents' Perceptions

\begin{tabular}{lll}
\hline Service Quality Dimension & $\begin{array}{l}\text { Perceptions } \\
\text { N of Items }\end{array}$ & Cronbach's Alpha \\
\hline Tangibles & 4 & 0,697 \\
Assurance & 4 & 0,766 \\
Reliability & 5 & 0,838 \\
Responsiveness & 4 & 0,782 \\
Empathy & 5 & 0,784 \\
Overall & $\mathbf{2 2}$ & $\mathbf{0 , 9 2 3}$ \\
\hline
\end{tabular}

However, the reliability score in terms of perceptions of service quality dimension (Tangibles) was 0.697. This means reliability service quality dimension, did not meet the recommended Cronbach's alpha value of 0.70 reliability threshold. This does not mean it is poor, for the fact that, Cronbach's alpha value is considered to be poor, if it is less than 0.60 (Islam, et al., 2011). The overall reliability scores for both expectations $(0.908$ as shown in table 4 ) and perceptions of service quality ( 0.923 for perceptions as shown in table 9 ) exceeded the recommended Cronbach's alpha value of 0.70 reliability thresholds.

Factor Analysis: Is a statistical technique whose main goal is data reduction. A typical use of factor analysis is in survey research, where a researcher wishes to represent a number of questions with a small number of hypothetical factors. Factor analysis/loading show inter-correlations between variables the statements that constituted each dimension loaded perfectly along a single component for expectations and perceptions. This implies that the statements that constituted these sections perfectly measured what it set out to measure.

Table 5: Rotated Component Matrix

\begin{tabular}{|c|c|c|c|}
\hline & Research area & Expectations & Perceptions \\
\hline TAN 1 & $\begin{array}{l}\text { PTVET } \\
\text { equipment } \\
\text { excellency }\end{array}$ & 0,734 & $\begin{array}{l}0,7 \\
95\end{array}$ \\
\hline TAN 2 & $\begin{array}{l}\text { PTVET } \\
\text { Facilities } \\
\text { excellency }\end{array}$ & 0,759 & $\begin{array}{c}0,8 \\
3\end{array}$ \\
\hline TAN 3 & $\begin{array}{l}\text { PTVET } \\
\text { materials } \\
\text { availability }\end{array}$ & 0,709 & $\begin{array}{l}0,7 \\
41\end{array}$ \\
\hline TAN 4 & $\begin{array}{l}\text { PTVET } \\
\text { workforce } \\
\text { performance } \\
\text { PTVET }\end{array}$ & 0,56 & $\begin{array}{l}0,5 \\
03\end{array}$ \\
\hline Assur 5 & $\begin{array}{l}\text { workforce } \\
\text { behavioural } \\
\text { conduct } \\
\text { PTVET }\end{array}$ & 0,767 & 0,792 \\
\hline Assur 6 & $\begin{array}{l}\text { customers } \\
\text { safety }\end{array}$ & 0,724 & 0,748 \\
\hline Assur 7 & $\begin{array}{l}\text { PTVET } \\
\text { workforce } \\
\text { customers } \\
\text { treatment }\end{array}$ & 0,813 & 0,791 \\
\hline
\end{tabular}




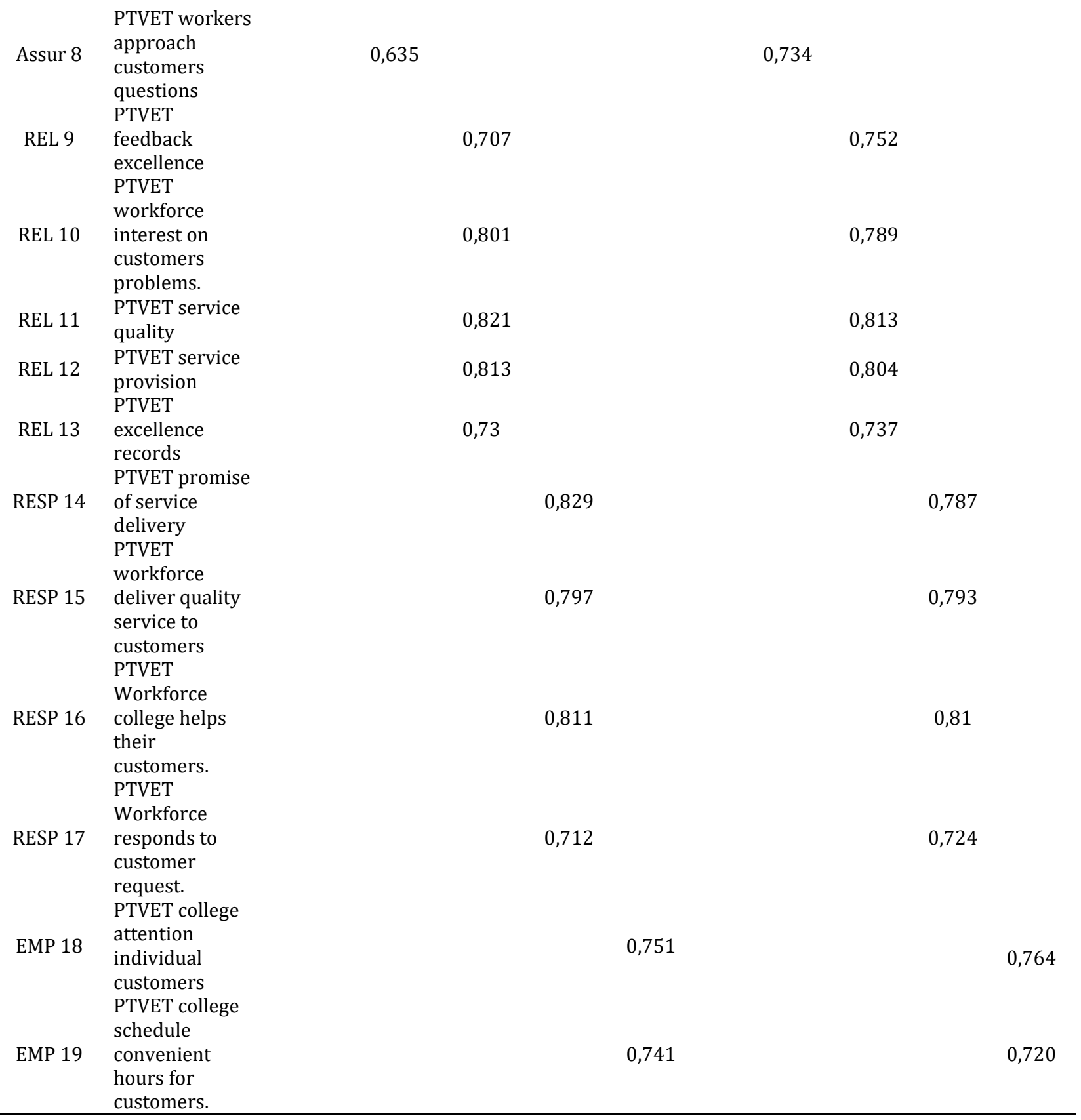

The conducted factors analysis results revealed that, 0.734 (expectations) and 0,795 (perceptions) the presented the strong value for the customer service quality choice. This means that, these variables (expectations and perceptions) has sufficient influence on how customer perceived PTVET quality service. With regards to the results based on PTVET facilities Excellency show that, 0.734 (expectations) and 0, 83 (perceptions), this means that, these variables have a strong influence for the PTVET customer service quality. Responses on PTVET materials availability, 0,709 (expectations) and 0,741 (perceptions) as shown in Table 5). This indicates materials availability as an important variable on judging quality service at PTVET colleges. However, 0, 56 (expectations) and 0,503, revealed that, this variable does not have much influence in judging service quality provided by PTVET. The results show 0,767 (expectations) and 0,792 (perceptions) on PTVET workforce behavioural conduct. 
This result suggests that; this variable has a strong significance for the PTVET customers to judge service quality provided by PTVET colleges. With regards to PTVET customers' safety, results (expectations: 0,724 and perceptions: 0,748) also has a strong impact on customer service quality judgement. On the other hand, PTVET workforce customer treatment has 0,813 (expectations) and 0,791 (perceptions). This presents the strong value for customer service quality choice. Responses regarding PTVET workers approach customer's questions showed that 0,635 (expectations) and 0,734 (perceptions). Expectations value $(0,635)$ is not too strong, yet, showing strong significance in PTVET college quality service. On the other hand, perception value has a strong significance in customer service quality. The results based on PTVET feedback excellence showed that, 0,707 (expectations) and 0,752 (perceptions), the presented the strong value for the customer service quality choice. This means that, these variables (expectations and perceptions) has sufficient influence on how customer perceived PTVET quality service.

On the other hand, PTVET workforce interest on customer's problems has value 0,801(expectations) and 0,789 (perceptions). This result showed a strong value for the customer service quality choice. The feedback on PTVET service quality showed that 0,821 (expectations) and 0,813 (perceptions) displayed the strong value for the customer service quality choice. This means that, these variables have sufficient influence on how customer judge service provided by PTVET colleges. However, the responses on PTVET service provision showed the value of 0,813 (expectations) and 0,804 (perceptions), this also presents the strong sufficient influence on customer service quality judgement. With regards to PTVET excellence records, 0,73 (expectations) and 0,737 (perceptions), this results indicate that, this variable has a positive impact on how PTVET customer's judgement. Whereas, the results with regards to PTVET promise of service delivery has a value of 0,829 (expectations) and 0,787 (perceptions). This result also shows the strong sufficient impact on customer's service quality judgment.

PTVET workforce delivers quality service to customers has 0,797 (expectations) and 0,793 (perceptions) value, signifying that this value does have a strong significance on customer's service quality judgement. However, PTVET Workforce college helps their customers have 0,811 (expectations) and 0, 81 (perceptions), also shows a strong significant variable on PTVET customer service quality. In other hand, PTVET Workforce college helps their customers have 0,811 (expectations) and 0,81 (perceptions), these results indicate the positive impact of these variables for the customer service quality. With regards PTVET Workforce respond to customer request has 0,712 (expectations) and 0,724 (perceptions) value, this results also indicates strong significance on PTVET customers judging service quality at PTVET colleges. Feedback regarding PTVET college attention individual customers showed 0,751 (expectations) and 0,764 (perceptions), these variables present the strong significance of customer's service quality choice. However, value for PTVET college schedule convenient hours for customers were 0,741 (expectations) and 0,720, these variables are also strong.

Table 6: Kaiser-Meyer-Olkin (KMO) and Bartlett's Test

\begin{tabular}{|c|c|c|c|c|c|c|c|c|}
\hline \multirow{3}{*}{$\begin{array}{l}\text { Service Quality } \\
\text { Dimensions }\end{array}$} & \multicolumn{4}{|l|}{ Expectations } & \multicolumn{4}{|l|}{ Perceptions } \\
\hline & \multirow{2}{*}{$\begin{array}{l}\text { Kaiser-Meyer- } \\
\text { Olkin } \\
\text { Measure of } \\
\text { Sampling } \\
\text { Adequacy }\end{array}$} & \multicolumn{3}{|c|}{$\begin{array}{l}\text { Bartlett's Test of } \\
\text { Sphericity }\end{array}$} & \multirow{2}{*}{$\begin{array}{l}\text { Kaiser-Meyer- } \\
\text { Olkin } \\
\text { Measure of } \\
\text { Sampling } \\
\text { Adequacy }\end{array}$} & \multicolumn{3}{|c|}{$\begin{array}{l}\text { Bartlett's Test of } \\
\text { Sphericity }\end{array}$} \\
\hline & & $\begin{array}{l}\text { Approx. } \\
\text { Chi-Square }\end{array}$ & DF & Sig. & & $\begin{array}{l}\text { Approx. } \\
\text { Chi- } \\
\text { Square }\end{array}$ & DF & Sig. \\
\hline Tangibles & 0.705 & 195.789 & 6 & 0.000 & 0.705 & 312.955 & 6 & 0.000 \\
\hline Assurance & 0.731 & 312.404 & 6 & 0.000 & 0.774 & 383.874 & 6 & 0.000 \\
\hline Reliability & 0.845 & 709.126 & 10 & 0.000 & 0.851 & 716.212 & 10 & 0.000 \\
\hline Responsiveness & 0.782 & 477.254 & 6 & 0.000 & 0.785 & 429.559 & 6 & 0.000 \\
\hline Empathy & 0.791 & 522.587 & 10 & 0.000 & 0.783 & 534.280 & 10 & 0.000 \\
\hline
\end{tabular}

The above-mentioned variables presented Table 6, identified as most critical factors contributing to the expectations and perceptions of PTVET college customers. The finding of this study revealed that tangibles in terms of the expectations and perceptions 0.705 and 0.705 . This means this service quality dimension has a positive impact on customer expectations as well as on the customer perceptions. With regards to the 
assurance dimension results indicated that 0.731 and 0.774 have positive influencing on the service quality of PTVET colleges as perceived by customers. On the other hand, results indicated 0.845 and 0.716 as reliability dimension significance to the service quality. While 0.782 and 0.785 shown the significance responsiveness to the service quality. The last dimension of quality service known an empathy, Table 6 shows that expectations and perceptions have 0.791 and $0.783 \mathrm{KMO}$ measure of sampling adequacy in respectively.

The Limitations of this Study: The study was only confined to KwaZulu- Natal province. 403 hard copies of questionnaires were distributed to the selected PTVET Colleges operating in KZN. The findings of this study can only be used with care, therefore, it is very important to note that PTVET Colleges from other provinces are not included then generalizations of this finding should be made with utmost care. The implications of this study are of twofold: Theoretical implications and practical implications. The detailed discussion of these concepts presented in the following sections.

Implications on Customer Expectations toward PTVET: Having established a considerate of customer expectations in describing its contextual, it clears why customer expectation is an important subject in the TVET sector. Failure for PTVET colleges to understand the level of service their customers (which are students, parents, and employers) expects will lead to losing customers to their competitions who can meet their expectations. According to the findings for this study shows that, customers (who are students) they expect more from the PTVET.

Implications of Customer Perceptions toward PTVET: According to Khare (2011) perceptions of customers becomes a powerful feature concerning customers' satisfaction. When PTVET colleges rendered service that is below their customers' expectations, this resulted in dissatisfaction. The findings of the study indicate that, customer perceptions (which are students) are low, which means, the selected PTVET colleges they fail to satisfy the need of their customers. The following figure 2 shows the overall outcome of this study, in terms of service quality of customer expectations and perceptions gaps as Hudson \& Hudson (2012) revealed that, if their customer expectations are met or exceed then customers will usually believe that they received high-quality service. The overall results based on customer expectations and perception of all five service quality dimensions shows that, customer expectations (average mean of 3.81) were higher than customer perceptions (average mean of 3.22) resulted to a gap of -0,50. Customers' expectations were higher than what was perceived from the selected PTVET Colleges. This resulted in customers' dissatisfaction. However, dissatisfied customers will spread bad marketing through words of mouth to their friends and family members (Zungu, 2013).

Figure 2: The Overall Results of this Study

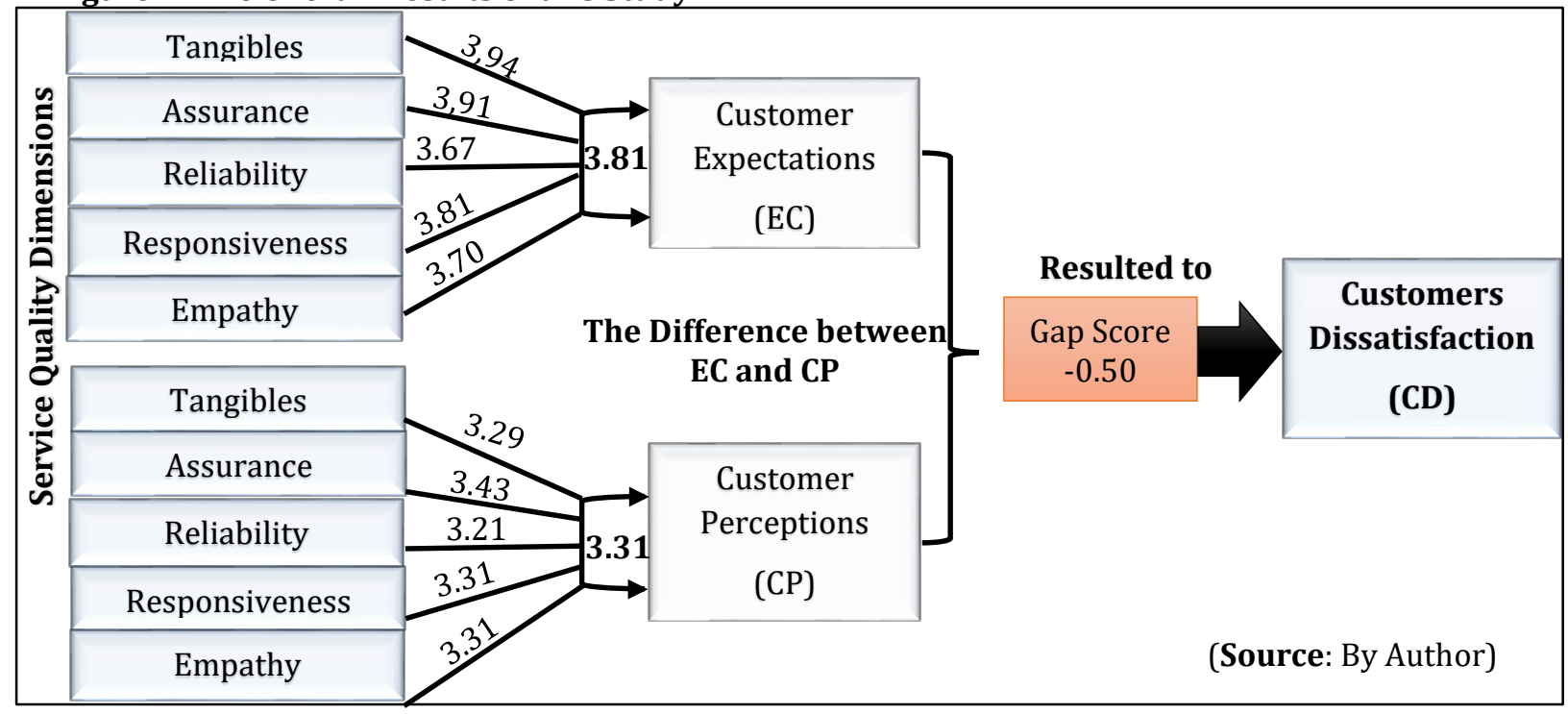




\section{Conclusion}

From the research findings, this article can conclude that customers' expectations of service quality in an excellent PTVET college are higher than their perceptions of service quality at the selected PTVET college campuses therefore this proves that the customer expectations of service quality are not in line with the acceptance levels of service quality in the PTVET sector. Customers have higher service quality expectations that if not me by the PTVET can result in customer dissatisfaction and losing customers to their competitors.

Recommendations: There is a clear indication from the findings that much still needs to be done by PTVET colleges and some negative implications have been identified. The results of the study have revealed that customers have high expectations of service quality in PTVET sector.

\section{References}

Boshoff, C. \& du Plessis, F. (2010). Service Marketing: Contemporary approach. Juta and Company Ltd: Cape Town.

Boshoff, C. (2014). Services Marketing: A contemporary approach. $2^{\text {nd }}$ ed. Juta and Company Ltd. Cape Town

Bünning, F. \& Zhao, Z. (2006). TVET Teacher Education on the Threshold of Internationalization. UNEVOC: International Centre for Technical Vocational Education and Training.

Cant, M. C., Brink, A. \& Brijball, S. (2002). Customer Behaviour: A South African perspective. Cape Town: Juta.

Hudson, S. \& Hudson, L. (2012). Understanding the consumer: Customer service in Tourism and Hospitality. Oxford: good fellow publishers limited.

Hult, G. T. M., Pride, W. M. \& Ferrell, O. C. (2013). Marketing. $17^{\text {th }}$ Edition. Australia South Cengage Learning.

Islam, A. M. D., Khan, M. A., Obaidullah, Z. M. \& Alam, M. S. (2011). Effect of Entrepreneur and Firm Characteristics on the Business Success of Small and Medium Enterprises (SMEs) in Bangladesh, International Journal of Business and Management, 6 (3), 1-15.

Khare, A. (2011). Customers' Perception and attitude towards service quality in multinational Banks in India. Int. J. Services and Operations Management, 10(2), 199-2015.

Machado, R. \& Diggines, C. (2012). Customer Service. Cape Town: Juta.

Mohd, Z. I., Mohd N. A. R. \& Ruhizan, M. Y. (2012). Assessing Students Perceptions of Service Quality in Technical Educational and Vocational Training (TEVT) Institution in Malaysia. Procedia: Social and Behavioral Sciences, 56, 272-283.

Phiri, M. A. \& Mcwabe, T. (2013). Customers' expectations and perceptions of service quality: The case of pick 'n pay supermarket stores in Pietermaritzburg Area, South Africa. Internal Journal of Research in Social Sciences, 3(1), 96-104.

Pillay, M. A., Mbambo, S. N. \& Mason, R. B. (2017). Service Quality's Role in Students' Decisions to Study at Further Education and Training Colleges. International Journal of Educational Sciences, 18(1-3), 87-100.

Schiffman, L. \& Kanuk, L. L. (2000). Consumer Behavior. $7^{\text {th }}$ Edition. Pearson.

Sheth, J. \& Mittal, B. (2004). Customer Behavior: A managerial perspective. $2^{\text {nd }}$ Ed. Canada: Thomson SouthWestern.

Shirley, A. C., Chijioke, O. P. \& Chukwumaijem, O. B. (2015). Towards Quality TVET (Technical and Vocational Education and Training) Programmes in Nigeria: Challenges and Improvement strategies. Canadian Center of Science and Education.

Strydom, J. W., Cant, M. C. \& Jooste, C. J. (2000). Marketing Management. $4^{\text {th }}$ Edition. Cape Town: Juta.

Wilson, A., Zeithaml, V. A., Butner, M. J. \& Gremler, D. D. (2013). Service Marketing. $4^{\text {th }}$ Edition. McGraw-Hill Education.

Wolhuter, B. (2017). Scramble for varsity place, The Mercury, 10 January: 2017

Zeithaml, V. A., Bitner, M. J. \& Gremler, D. D. (2006). Service marketing customer focus across the firm. $4^{\text {th }}$ Ed. New York: McGraw-Hill.

Zeithaml, W. A., Bitner, V. A., Grender, M. J. \& Dwayne, D. (2008). Services marketing: Integrating customer focus across the firm. London: McGraw-Hill.

Zimmerman, A. \& Blythe, J. (2014). Business to Business Marketing Management: A Global Perspective. $2^{\text {nd }}$ Edition. London and New York: Routledge Taylor and Francis Group.

Zungu, N. P. (2013). Service quality at retail banks in Durban. Degree of Master of Technology: Marketing, Durban University of Technology. 